\title{
GEOLOGIC MAP OF THE KRUMBO RESERVOIR QUADRANGLE, HARNEY COUNTY, SOUTHEASTERN OREGON
}

\author{
By Jenda A. Johnson
}

\section{INTRODUCTION}

The Krumbo Reservoir 7.5-minute quadrangle encompasses parts of the Blitzen Valley and northwestern flank of Steens Mountain in the Basin and Range physiographic province of southeastern Oregon (fig. 1). The entire map area is underlain by a bimodal assemblage of middle and upper Miocene olivine basalt flows and rhyolite ash-flow tuffs (figs. 2 and 3). This assemblage is characteristic of volcanic rocks in the northern $B$ asin and Range province and is thought to result from Cascade Range back-arc volcanic activity (Hart and Carlson, 1987). Locally derived Quaternary alluvium blankets part of the area. Faulting associated with Basin and Range extension has created the north-trending Blitzen Valley. In contrast, west-northweststriking faults are parallel to and probably related to the Brothers fault zone, a northwest-trending zone of closely spaced, discontinuous fractures (Walker, 1969c; Lawrence, 1976).

\section{STRATIGRAPHY}

\section{STEENS BASALT}

The Steens Basalt, oldest unit exposed in the quadrangle, is a thick, laterally continuous sequence of lava flows widespread in southeastern Oregon (Fuller, 1931; Watkins and Baksi, 1974; Hart and Carlson, 1985). The flows extend from Abert Rim, $100 \mathrm{~km}$ west of the map area, into the Bilk Creek Mountains and Santa Rosa Range of Nevada (Mankinen and others, 1987). The Steens Basalt originally covered at least $15,000 \mathrm{~km}^{2}$ of southeastern Oregon with an average thickness of $1,000 \mathrm{~m}$ (Carlson and Hart, 1983).

Flows of the Steens Basalt in the Krumbo Reservoir quadrangle range in thickness from less than $1 \mathrm{~m}$ to more than $20 \mathrm{~m}$, and they average $3 \mathrm{~m}$ thick. Maximum thickness of the unit is $1,300 \mathrm{~m}$ along the Steens Mountain escarpment about $15 \mathrm{~km}$ southeast of the map area (Fuller, 1931; Minor and others, 1987c). In the map area, the unit has a maximum exposed thickness of $80 \mathrm{~m}$; its base is not exposed. The Steens Basalt is underlain by lower Miocene intermediate and silicic volcanic rocks exposed 25 $\mathrm{km}$ east of the map area at the base of the Steens Mountain (Fuller, 1931; Walker, 1979).

Joints in the flows are randomly oriented. Sedimentary materials are absent between flows, indicating rapid accumulation of lava. Samples of the Steens Basalt collected in the Krumbo Reservoir quadrangle are chemically similar to those from the Steens Mountain escarpment (table 1; fig. 4). The high alumina and strontium content of the porphyritic sample, No. JK90-4, results from plagioclase accumulation.

The Steens Basalt was erupted chiefly from subvertical dikes now exposed in the eastern range-front escarpment of Steens Mountain (Fuller, 1931). No vents for the Steens Basalt are exposed in the map area. Isotopic studies by Carlson and Hart (1983) indicate that the Steens Basalt was derived from a depleted oceanic-type mantle and erupted in an extensional back-arc basin $200 \mathrm{~km}$ east of the Miocene Cascade Range.

Potassium-argon whole-rock ages from the Steens Basalt range from 17.0 to $14.8 \mathrm{Ma}$ (Watkins and Baksi, 1974; Hart and Carlson, 1985). A more recent examination by Swisher and others (1990) yielded ages of $16.58 \pm 0.05 \mathrm{Ma}$ and $16.59 \pm 0.022 \mathrm{Ma}$, determined using ${ }^{40} \mathrm{Ar}-{ }^{39} \mathrm{Ar}$ laser fusion of coarse plagioclase crystals from flows 1 and 31 , respectively, at the type section (numbered upward from base). The Steens Basalt is contemporaneous with much of the Columbia River Basalt Group of northeastern Oregon and eastern Washington (Walker, 1969b; Hart and others, 1989). The Steens Basalt interfingers in its uppermost part with the 16.1-Ma tuff of Oregon Canyon east of the Steens Mountain escarpment in the Sheepshead Mountains (Sherrod and others, 1989).

The Steens Basalt at its type section exhibits, from base to top, a polarity sequence of normal-reversed-normal (Watkins and Baksi, 1974; Mankinen and others, 1987). Normal-polarity magnetization was measured in two flows sampled in the map area with a portable fluxgate magnetometer. These flows presumably correspond to the upper normally polarized zone, assuming that the upper flows on the dip slope of Steens Mountain reach as far west as the Blitzen Valley.

\section{TUFF AND TUFFACEOUS SEDIMENTARY ROCKS}

Poorly indurated tuffaceous rocks that are exposed in only a few canyon walls and road cuts in the map area disconformably overlie the Steens Basalt and are disconformably overlain by the Devine Canyon Ash-flow Tuff. Thickness of the sedimentary rocks ranges from less than $3 \mathrm{~m}$ to more than $60 \mathrm{~m}$; variation in thickness over lateral distances of a few hundred meters reflects erosional topography that existed during deposition. These strata are locally absent in the southern part of the Krumbo Reservoir quadrangle.

A continuous exposure nearly $30 \mathrm{~m}$ thick is present in a canyon wall southeast of Krumbo Reservoir. There the unit is composed of poorly indurated, fine- to medium- 


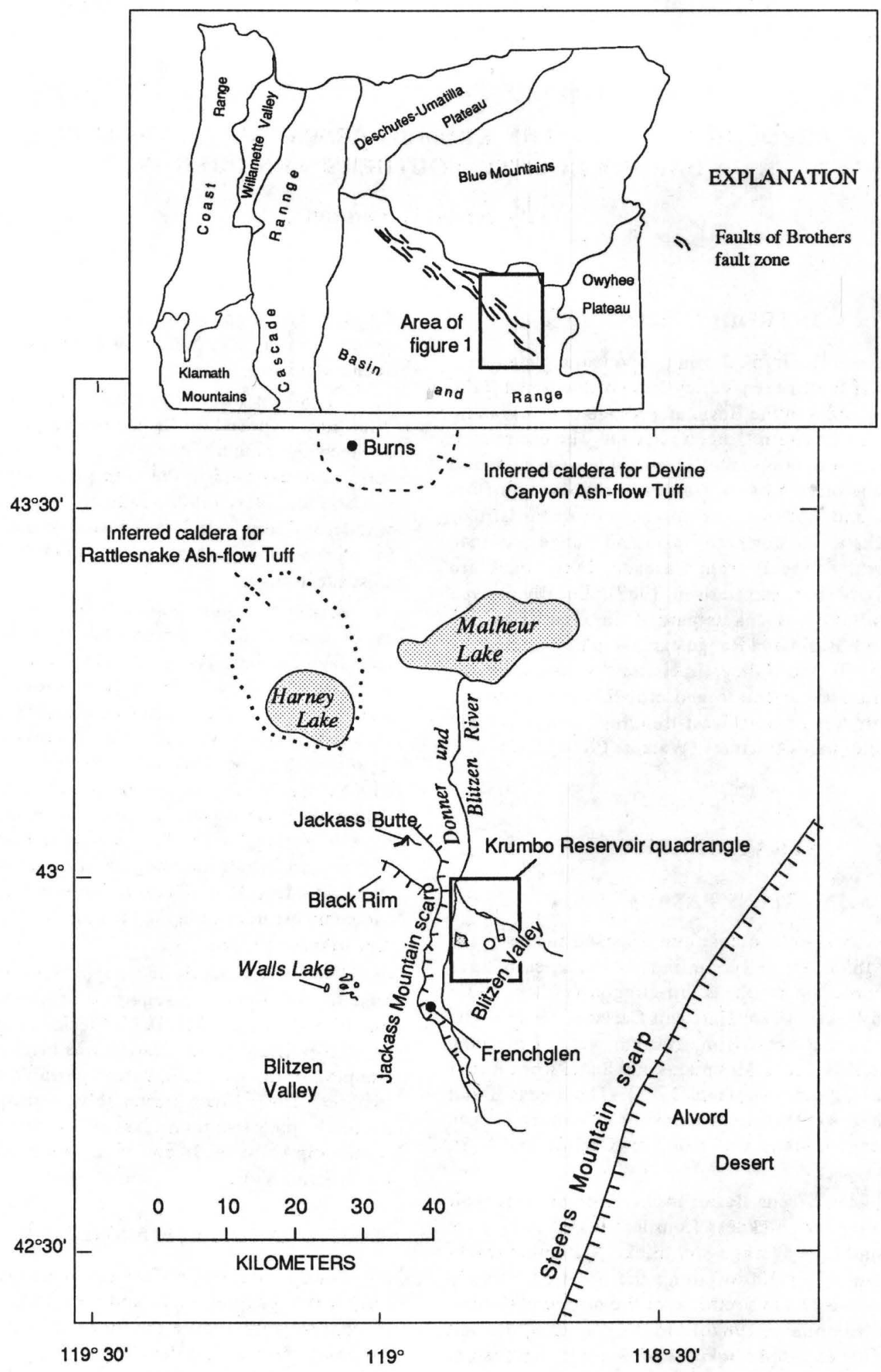

Figure 1. Physiographic and geographic setting of study area. Inset map shows physiographic provinces of Oregon and Brothers fault zone.

grained glass shards, partially reworked ashy deposits, and poorly sorted sandstone. A discontinuous basal lens of crystal-rich, medium-grained sandstone lies just above the contact with the underlying Steens Basalt.
The tuff and tuffaceous sedimentary rocks were included with the Devine Canyon Ash-flow Tuff and Rattlesnake Ash-flow Tuff as a single map unit on the reconnaissance map by Walker and Repenning (1965), owing 
$118^{\circ} 52^{\prime} 30^{\prime \prime}$

$43^{\circ}$

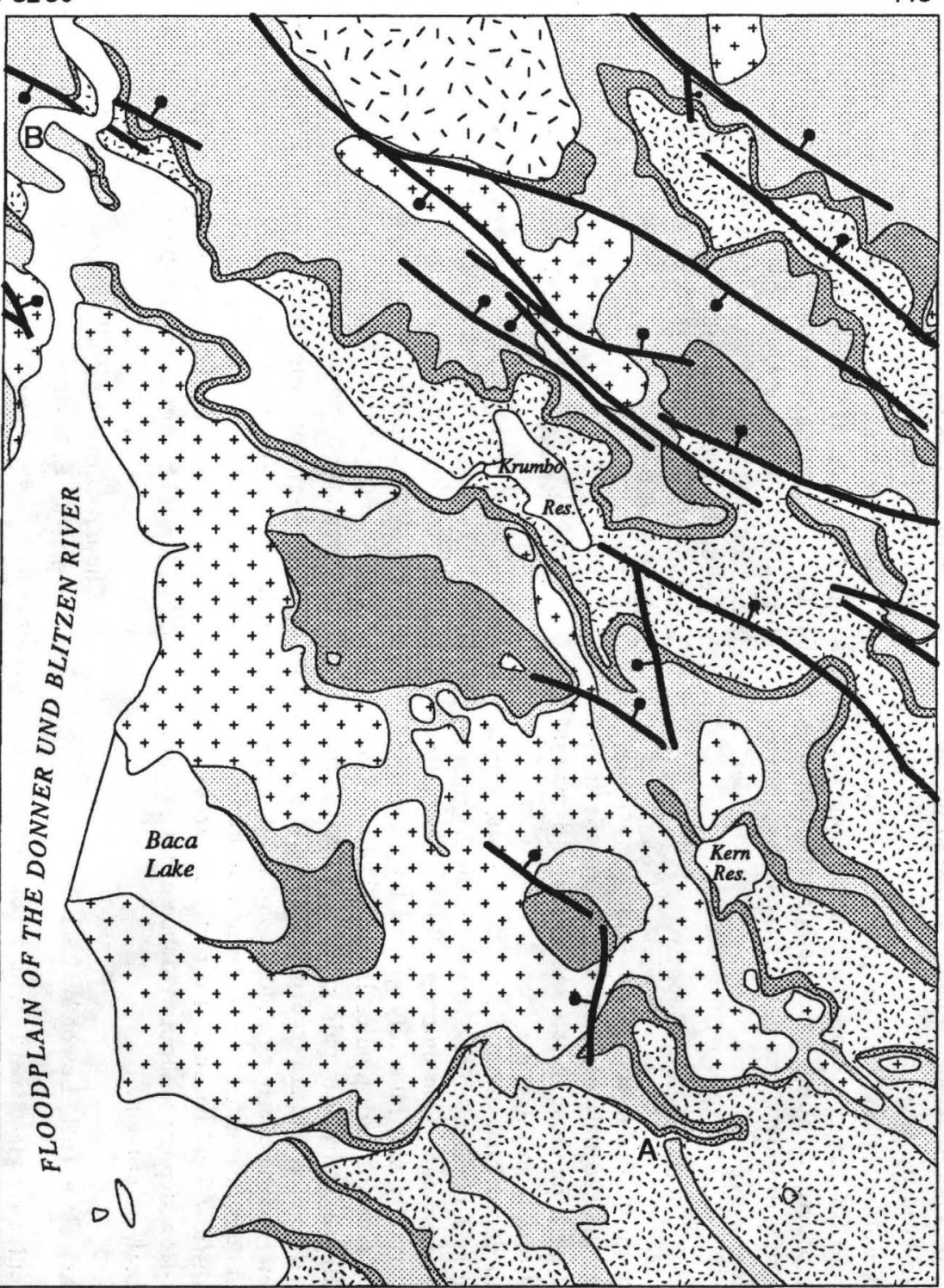

\section{EXPLANATION}

Alluvium (Quaternary)

Rattlesnake Ash-flow Tuff (Miocene) - 6.7 Ma

Basalt of Hog Wallow (Miocene)

Devine Canyon Ash-flow Tuff (Miocene)-9.5 Ma

Tuff and tuffaceous sedimentary rocks (Miocene)

Steens Basalt (Miocene)-16.5 Ma

\section{Contact}

Fault-Ball and bar on downthrown side

Location of paleoconfluence (southeast corner of map area)

Location of Pleistocene meander loop (northwest corner of map area)

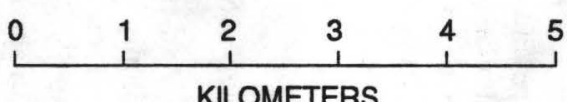

Figure 2. Generalized geologic map of the Krumbo Reservoir quadrangle. 
to the scale of the map. The rocks are lithologically similar to and perhaps temporally correlative with the Mascall Formation, which contains vitric tuff and tuffaceous sandstone as well as gravel and conglomerate (Davenport, 1971). An ash-flow tuff in the Mascall Formation has a $\mathrm{K}$-Ar age of 16.2 $\pm 1.4 \mathrm{Ma}$ (Davenport, 1971; age reported here is recalculated by Fiebelkorn and others, 1983). Although mammalian fossils of Barstovian age (middle Miocene) were found in this unit $25 \mathrm{~km}$ west of map area in Keg Springs Valley (G.W. Walker, written commun., 1992; for location see Walker and Repenning, 1965), no fossils were found in the tuffaceous rocks in the map area.

\section{DEVINE CANYON ASH-FLOW TUFF}

The Devine Canyon Ash-flow Tuff is a distinctive crystal-rich tuff that originally covered more than 18,600 $\mathrm{km}^{2}$ of southeastern Oregon and had a volume of approximately $195 \mathrm{~km}^{3}$ (Greene, 1973). The tuff is a sheet-forming unit in the northern half of the map area but forms elongate southeast-trending lobes in the southern part (see section on paleogeography). The Devine Canyon Ash-flow Tuff disconformably overlies the unit of tuff and tuffaceous sedimentary rocks (Tts) and has a maximum preserved thickness of $30 \mathrm{~m}$ near its type locality $13 \mathrm{~km}$ north of Burns (Greene, 1973; Walker, 1979). Outcrops in the map area represent the southeastern distal margin of the tuff; maximum thickness there is about $17 \mathrm{~m}$ but averages $7-10 \mathrm{~m}$. Measured thicknesses represent minimum values, however, because the nonwelded to poorly welded uppermost part of the unit has been removed by erosion.

Densely welded, crystal-rich ash-flow tuff forms most of the Devine Canyon Ash-flow Tuff in the map area. Complete exposures comprise a coeruptive basal pumicefallout deposit, vitrophyre, and densely welded and moderately welded tuff.

\section{Basal Fallout Deposit}

This unconsolidated interval varies from pale yellowish gray to light gray to pale orange. The deposit is fairly well sorted with pumiceous ash and lapilli 1-3 $\mathrm{mm}$ in diameter; it ranges in thickness from 1.3 to $1.8 \mathrm{~m}$. The basal fallout deposit has about 3 percent crystals, which are as large as $1 \mathrm{~mm}$, and black to gray lithic fragments $0.5-1 \mathrm{~cm}$ in diameter. One outcrop exhibits alternating layers of normally and reversely graded tephra capped sharply by a layer of dark pumice lapilli. The blackishbrown lapilli are frothy with pale-gray cores, range from $0.2-1 \mathrm{~cm}$ in diameter, and are incorporated into the lower few centimeters of the overlying welded ash-flow tuff. The basal fallout deposit is considered to be part of the Devine Canyon Ash-flow Tuff because it directly underlies the pyroclastic-flow deposit without evidence of intervening sediment, soil, or erosion.

\section{Ash-flow Tuff, Lower Welded Zone}

Clear eutaxitic glass shards with a tan dusty matrix form 70-90 percent of the ash-flow tuff. There is little devitrification of the shards, which are generally flattened and parallel to the flow margins but locally molded against crystals. Spherulites $3-5 \mathrm{~mm}$ in diameter form 3 percent of the tuff. Chemical analysis of a pumice lapillus from this zone collected $9 \mathrm{~km}$ west of the map area (sample IL90 , table 1) yielded a rhyolite composition.

A 5-m-thick, poorly developed lithophysal zone is locally present. The ash-flow tuff in this zone weathers at the base to $2-\mathrm{cm}$ balls of welded tuff partly surrounded by narrow voids. In its upper part, this zone contains gas cavities $2 \mathrm{~cm}$ high and $5 \mathrm{~cm}$ long. Overall, the zone shows greater devitrification as cryptocrystalline spherulites (as much as 20 percent) than does the rest of the densely welded tuff. In thin section no textural variation is observed across the boundary of the balls.

\section{Ash-flow Tuff, Upper Welded Zone}

The platy, upper, moderately welded part of the Devine Canyon Ash-flow Tuff is probably widespread but only locally exposed. Maximum thickness as inferred from float is about $5 \mathrm{~m}$, but outcrops rarely exceed $0.5 \mathrm{~m}$ thick. Proportion of phenocrysts appears uniform throughout the ash-flow tuff. This interval has delicate clear shards and thick tan shards that are not seen in the lower, densely welded zone. It also has a dustier matrix than the lower welded zone. Incipient devitrification has affected the matrix but not the shards.

\section{Origin and Age}

The Devine Canyon Ash-flow Tuff possibly formed during caldera-forming eruptions in the vicinity of Burns. Location of the vent near Burns is interpreted from isopach mapping (Greene, 1973).

Potassium-argon ages range from 8.5 to $9.7 \mathrm{Ma}$; weighted mean age is $9.5 \mathrm{Ma}$ (Walker, 1979; Greene, 1973). The Devine Canyon Ash-flow Tuff was previously known informally as the welded tuff of Devine Canyon by Greene (1973) and was included in the now-abandoned Danforth Formation by Piper and others (1939). It was formally named by Walker (1979) for its type locality about $14 \mathrm{~km}$ north of Burns, Oregon.

\section{BASALT OF HOG WALLOW}

The basalt of Hog Wallow is a lava flow covering about $4 \mathrm{~km}^{2}$. The basalt overlies the Devine Canyon Ash-flow Tuff, and its top is eroded; maximum preserved thickness is estimated to be about $12 \mathrm{~m}$. The unit is informally named for Hog Wallow Spring, which lies north of the map area in the Diamond Swamp quadrangle.

The basalt of Hog Wallow is a low-K, low-Ti subalkaline transitional tholeiite $\left(\mathrm{K}_{2} \mathrm{O} \leq 0.5\right.$ percent and $\mathrm{TiO}_{2}$ $\leq 2.0$ percent, table 1 ) as defined by Hart and others (1984). The basalt of Hog Wallow is chemically similar to other low-K, low-Ti basalts described by Draper (1991; see fig. 4).

The basalt of Hog Wallow was erupted from dikes in the map area. Exposures of vertically flow-jointed basalt dikes extend away from the lava flow and cut across the underlying Devine Canyon Ash-flow Tuff.

The basalt of Hog Wallow is similar in age and composition to other high-alumina olivine tholeiite in the northwestern Basin and Range province (Hart and others, 
1984; Draper, 1991). According to McKee and others (1983), parent magmas of lavas like the basalt of Hog Wallow originated in the upper mantle in the back-arc region of the Cascade Range, where the crust was thinned by extension. A petrographically similar (oikocrystic) basalt exposed at Black Rim, $10 \mathrm{~km}$ west (fig. 1), lies between the Devine Canyon and Rattlesnake Ash-flow Tuffs (Sherrod and Johnson, 1994). The basalt of Black Rim was erupted from a shield volcano at Jackass Butte, which lies $7 \mathrm{~km}$ northwest of the Krumbo Reservoir quadrangle (fig. 1). The basalt of Hog Wallow was previously mapped as part of the Steens Basalt by Piper and others (1939).

\section{RATTLESNAKE ASH-FLOW TUFF}

The Rattlesnake Ash-flow Tuff is a pumice-rich tuff that forms a widespread sheet in south-central Oregon. It is exposed over a region of $22,000 \mathrm{~km}^{2}$ (Walker, 1979) and originally covered nearly $50,000 \mathrm{~km}^{2}$ (Parker, 1974). More recent work by M.L. Streck (Oreg. State Univ., oral commun., 1992) defines an original areal extent of 38,000 $\mathrm{km}^{2}$ and an original volume of approximately $220 \mathrm{~km}^{3}$.

The Rattlesnake Ash-flow Tuff is the youngest volcanic unit in the map area. It lies concordantly on the Devine Canyon Ash-flow Tuff and is overlain unconformably by Quaternary alluvium.

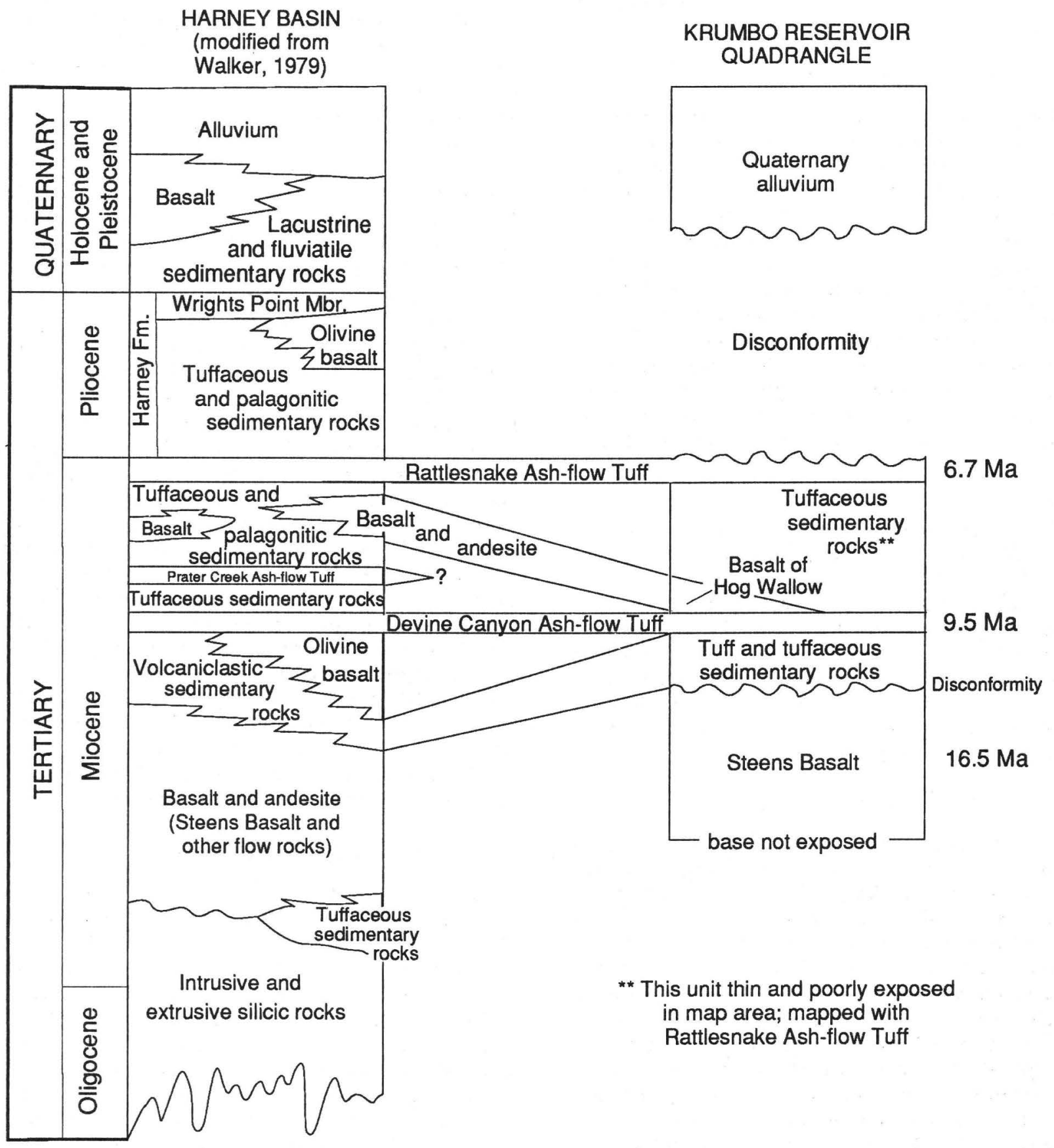

Figure 3. Comparison between stratigraphic units in Harney Basin region and units exposed in Krumbo Reservoir quadrangle. 
The unit ranges in thickness from 2 to $40 \mathrm{~m}$, including a poorly exposed sequence of unindurated volcaniclastic deposits. The welded, cliff-forming part of the ash-flow tuff in the map area averages $3 \mathrm{~m}$ thick and rarely exceeds $4 \mathrm{~m}$. The welded part of the unit is thicker than $60 \mathrm{~m}$ near its source in the west-central part of Harney Basin, about $40 \mathrm{~km}$ northwest of the map area (Walker, 1979).

In the map area, the Rattlesnake Ash-flow Tuff consists of two texturally distinct parts. The lower part is a poorly welded vitric lapilli ash-flow tuff and is the most widely exposed part of the Rattlesnake Ash-flow Tuff. The upper part is a platy, moderately welded devitrified ashflow tuff found only locally, typically above the lower part, but in one location directly overlying the Steens Basalt. Poorly consolidated volcaniclastic strata locally underlie the lower part.

\section{Lower Part}

The distinctive features of the lower part of the Rattlesnake Ash-flow Tuff are the abundance of pumice lapilli and the paucity of phenocrysts in the matrix. An analysis of a light-colored pumice bomb (table 1) indicates a rhyolitic composition. The composition of this pumice bomb, JK90-Tr, along with those analyzed by M.L. Streck (unpub. data, 1992) is shown in figure 4. Clear and brown glass shards and bubble walls, which form the matrix of the ash-flow tuff, are well preserved. The relative abundance of clear versus brown shards varies, but the clear shards are consistently larger than the brown. Proportion of shard types remains unchanged upsection. Volcanic rock fragments, consisting entirely of fine-grained plagioclase and an altered matrix, are scarce and rarely exceed $2 \mathrm{~mm}$.

\section{Upper Part}

The upper part of the Rattlesnake Ash-flow Tuff is platy, moderately welded, and devitrified stony tuff. This part is found only on four hills in the southeastern part of the map area but is widespread west of the map area. It has a characteristic speckling, thought to result from iron diffusing into the matrix from small (less than $2 \mathrm{~mm}$ ) xenoliths or from brown patches of an unknown material (Davenport, 1971). The rock is resistant to erosion owing to welding and devitrification. Average thickness is 0.5 $\mathrm{m}$; maximum thickness in the map area is $6-7 \mathrm{~m}$.

\section{Underlying Volcaniclastic Strata}

A massive, fine-grained, poorly consolidated, tuffaceous sedimentary sequence underlies the main part of the Rattlesnake Ash-flow Tuff. The only outcrop of this sequence is a 6-m-thick section exposed in a quarry adjacent to Kern Reservoir. The sequence at this locality is composed of poorly sorted, brown to honey-colored, submicroscopic ash shards and 5 to 10 percent broken, fine-grained crystals of alkali feldspar, quartz, plagioclase, and pyroxene. It also has pumice lapilli and medium-grained aggregates of incipiently devitrified glass shards enveloped in dark, honey-brown coronas. Color varies from grayish orange to pale moderate yellowish brown. Steeply dipping joints strike N. $5^{\circ}$ W. to N. $20^{\circ}$ W. and are filled with caliche. Rounded concretions with thin black manganese coatings weather out from the lower, slightly more indurated part of the sequence.

This sequence has been included with the Rattlesnake Ash-flow Tuff because it is too poorly exposed to map separately. A possibly correlative unit elsewhere in the region might be tuffaceous sedimentary deposits associated with the Prater Creek Ash-flow Tuff present in the Burns area (Walker, 1979).

\section{Origin and Age}

The Rattlesnake Ash-flow Tuff formed as a single cooling unit. Emplacement units, which range in composition from rhyolite at the base to dacite at the top of the Rattlesnake Ash-flow Tuff (M.S. Streck, unpub. data, 1992), were the result of material violently ejected from vents in several pulses. The source caldera has been interpreted to lie buried beneath Quaternary sedimentary deposits in a triangular area opening westward and northwestward for $50 \mathrm{~km}$ from the Harney Lake area (Streck, 1991; fig. 1).

The Rattlesnake Ash-flow Tuff has been dated isotopically at several localities (for example, Parker, 1974; Greene and others, 1972; Davenport, 1971). Most ages range from 5.54 to $6.8 \mathrm{Ma}$ and have a weighted mean age of about 6.7 Ma. A recently determined ${ }^{40} \mathrm{Ar}-{ }^{39} \mathrm{Ar}$ age from alkali feldspar is about $7.05 \pm 0.02 \mathrm{Ma}$ (error is 2-sigma) (A.L. Grunder, oral commun., 1992).

Many different names have been applied to the rocks comprising the Rattlesnake Ash-flow Tuff. Its rocks were first included in a sedimentary sequence exposed in the John Day River valley-the Rattlesnake Formation of Merriam and others (1925). Other workers recognized the ash-flow tuff as the more widespread, stratigraphically important part of the formation and renamed it the (informal) Rattlesnake ignimbrite of the Danforth Formation (Davenport, 1971) or the Rattlesnake Ignimbrite Tongue of the Rattlesnake Formation (Enlows, 1976). In the Harney Basin, the ash-flow tuff was first named the tuff-breccia member of the Danforth Formation by Piper and others (1939). Greene and others (1972) mapped it separately as the informally named welded tuff of Double $\mathrm{O}$ Ranch. Walker (1979) redefined the original Rattlesnake Formation to exclude its sedimentary strata and, for clarity, renamed the ignimbrite sheet the Rattlesnake Ash-flow Tuff (fig 3). The new reference locality (Walker, 1979) is at Poison Creek about $10 \mathrm{~km}$ north of Burns (fig. 1).

\section{QUATERNARY ALLUVIUM}

Unconsolidated Quaternary alluvium consists of gravel, sand, silt, and clay of the Donner und Blitzen River flood plain and locally derived sand and gravel that forms slope wash and talus deposits. No glacial deposits or evidence of a Pleistocene lake bed are present, although Walker (1977) indicated that shorelines surrounding Pleistocene Malheur Lake once extended across the western part of the map area and reached as far south as Frenchglen (fig. 1). A broad flat-floored meander loop in the northwest corner of the map area (loc. B on fig. 2), now occupied by the Donner und Blitzen River, probably formed during wetter parts of the Pleistocene. 
Table 1. Analyses showing major-and trace-element concentrations in Miocene rocks in the Krumbo Reservoir quadrangle

[Major-element analyses by Department of Geology, Washington State University, Pullman, Wash. All elements analyzed on an automatic Rigaku 3370 spectrometer using a single fused disk (ratio of lithium tetraborate to rock powder is 2:1). Each element is fully corrected for line interference and matrix effects of all other analyzed elements. Total iron expressed as $\mathrm{FeO}$ ]

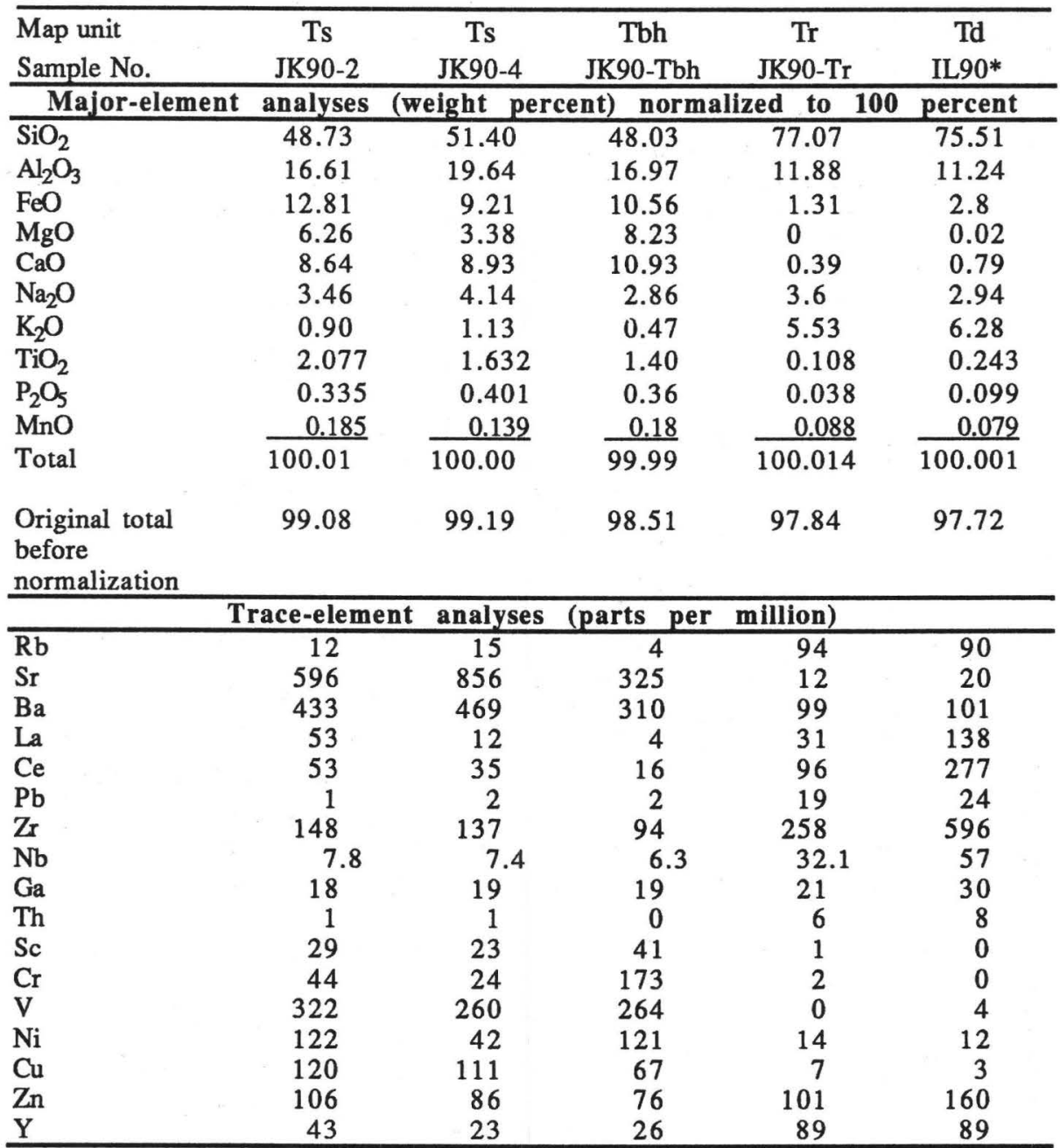

*From Irish Lake quadrangle, lat. $43^{\circ} 59.39 '$, long. $118^{\circ} 59.95^{\prime}$

\section{STRUCTURE}

Normal faults form the structural grain of the Krumbo Reservoir quadrangle. Faults can be grouped into two broad sets on the basis of their orientation. The most conspicuous set in the map area comprises high-angle normal faults that strike N. $50^{\circ} \mathrm{W}$. to $\mathrm{N} .80^{\circ} \mathrm{W}$. and forms part of the northwest-striking en echelon faults of the Brothers fault zone (fig. 1), which extends across southeastern Oregon (Walker, 1969c; Lawrence, 1976).

A subordinate set of faults strikes approximately north and is parallel to the major graben-forming faults of the northwestern Basin and Range province. The Blitzen Valley rests in the lower part of a half-graben associated with the Steens Mountain tilted fault-block uplift. The central part of Steens Mountain is a homoclinal block that dips westward about $3^{\circ}$ into the Blitzen Valley (Fuller, 1931). Most volcanic rocks in the map area dip approximately $2^{\circ}$ to $3^{\circ}$ to the west-northwest in the map area.

Age of the faults is constrained as younger than the Rattlesnake Ash-flow Tuff (6.7 Ma). No angular unconformities were exposed that could place constraints on the timing of uplift of the Steens Mountain block. An episode of roughly east-west-directed extensional tectonism began about $16 \mathrm{Ma}$, synchronous with bimodal volcanism (Stewart, 1978; Minor, 1986). This stress regime is responsible for the north-south elongate fault blocks. Although there is no stratigraphic evidence for faulting before deposition of the Rattlesnake Ash-flow Tuff, paleogeographic patterns suggest that northwest-trending lineaments may 
have existed prior to Devine Canyon time (9.5 Ma). No evidence has been found for recent faults cutting the Quaternary alluvium.

\section{PALEOGEOGRAPHY}

In the southern part of the map area, west-northwest elongate erosional remnants of the Devine Canyon Ashflow Tuff form a topographic grain parallel to the Brothers fault zone. The lobes range from 0.1 to $0.8 \mathrm{~km}$ wide and are as long as about $5 \mathrm{~km}$.

I interpret the lobe-forming outcrops to result from thicker deposition of the ash flow in paleovalleys cut into the Steens Basalt and the tuff and tuffaceous sedimentary rocks (units Ts and Tts). Inverted topography results along the trace of paleovalleys due to preservation of erosion- ally resistant, thicker valley-filling parts of the Devine Canyon Ash-flow Tuff.

In the northern part of the map area, the tuff is sheetlike. South of the map area in the adjacent Page Springs quadrangle, where the outcrop pattern forms elongate lobes, the underlying sedimentary rocks are locally absent and the Devine Canyon Ash-flow Tuff unconformably overlies the Steens Basalt. The dip of the Devine Canyon Ashflow Tuff, calculated from the outcrop pattern, is about $2^{\circ}$ to $3^{\circ}$ west-northwest, similar to the regional dip of all units in this part of the Blitzen Valley.

Several lobes in the southern part of the map area bifurcate upslope away from the inferred source area of the Devine Canyon Ash-flow Tuff. In plan view these features resemble inverted stream confluences that have since been truncated by erosion (for example, fig. 2 , loc.

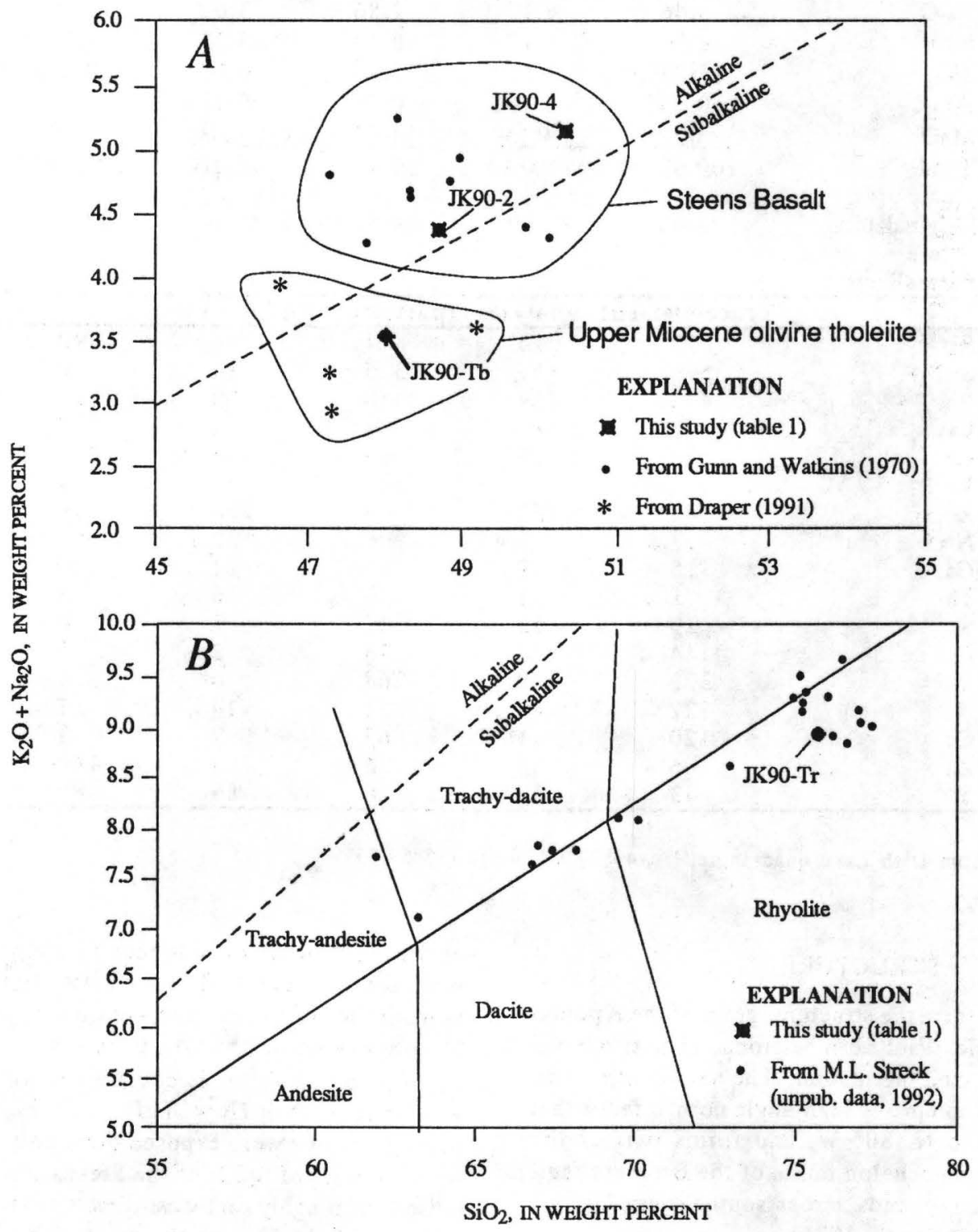

Figure 4. Alkali-silica diagram of some chemically analyzed units. Line separating alkaline from subalkaline rocks from Macdonald and Katsura (1964); alkali-silica classification diagram from Le Bas and others (1986). A, Middle Miocene Steens Basalt and upper Miocene high alumina olivine tholeiite. B, Upper Miocene Rattlesnake Ash-flow Tuff. 
A). No cobbles or other evidence of stream deposits were found beneath the Devine Canyon Ash-flow Tuff where its base is exposed along lobe axes.

Pyroclastic flows of the Devine Canyon Ash-flow Tuff probably covered the entire region but were thicker where they filled stream channels. According to Fisher and Schmincke (1984), large sheet-forming ignimbrites commonly have sufficient volume to vary in thickness across hills and valleys while maintaining a nearly flat upper surface. They describe channelized beds having a ten-fold greater thickness than laterally equivalent beds.

Field evidence indicates a gentle paleoslope on the western flanks of the Steens Mountain fault block. The absence of cobbles at the base of the Devine Canyon Ashflow Tuff suggests that the streams had a low gradient and carried only fine sediment. Meandering streams might be expected given the gentle slope of units and the fine-grained nature of the poorly indurated strata above the Steens Basalt. Yet the paleovalleys are parallel and relatively straight, and the structural trend mimics the west-northwest strike of faults in the northern part of the map area. These relations indicate that the pyroclastic flows filled paleovalleys that were structurally controlled by west-northwest-striking fractures developed prior to the emplacement of the Devine Canyon Ash-flow Tuff.

\section{DUTCH OVEN}

The most striking geographic feature in the map area is Dutch Oven, a large closed depression located in the southeastern part of the map area. It is roughly circular in plan view with an average diameter of about $1.6 \mathrm{~km}$. The depression is about $50 \mathrm{~m}$ deep with a total volume of $0.074 \mathrm{~km}^{3}$.

Three rock units are exposed in the walls. The oldest is the tuff and tuffaceous sedimentary rocks (Tts). Above this, the Devine Canyon Ash-flow Tuff forms a broad 6$\mathrm{m}$-high north-dipping shelf in the north half of the hole. Lack of outcrop of the Devine Canyon in the south half of the hole indicates either nondeposition of the tuff there, or erosion prior to emplacement of overlying units. About 25-30 m of poorly consolidated tuffaceous sedimentary rocks mapped with the Rattlesnake Ash-flow Tuff overlie the Devine Canyon Ash-flow Tuff. Talus and vegetation obscure any outcrop of the tuffaceous sedimentary rocks. A 5$\mathrm{m}$-thick layer consisting of a poorly welded zone of the Rattlesnake Ash-flow Tuff forms the encircling rimrock.

The rimrock is cut by two faults that probably intersect near the center of the depression. A N. $70^{\circ} \mathrm{W}$.-striking normal fault on the west rim drops strata 6 to $8 \mathrm{~m}$ lower on the north and appears to terminate several hundred meters from the edge; a north-striking fault on the southeastern rim has eastside-down displacement of 6 to $9 \mathrm{~m}$ and extends about $1 \mathrm{~km}$ south away from the depression.

The Harney Basin of southeastern Oregon contains at least six similar pits (Johnson and Sherrod, 1992). The pits have diameters ranging from 0.4 to $1.6 \mathrm{~km}$ and depths from 10 to $60 \mathrm{~m}$. In most cases, the pits are floored by poorly indurated sedimentary strata that underlie the Rattlesnake Ash-flow Tuff. The tuff is partially eroded and forms the regional surface. Any crater-rim deposits that may formerly have been present have been subsequently eroded. Other amphitheater-like re-entrants exposed in canyon walls in the region may be the remnants of pits breached by erosion; Baca Lake might be one of these. A few pits are cut by normal faults with offset of less than $10 \mathrm{~m}$. Other pits are in undeformed strata.

I interpret these depressions as relict secondary hydroexplosion pits that formed during emplacement of the Rattlesnake Ash-flow Tuff. Secondary hydroexplosions occur when hot pyroclastic flows cover streams, ponds, and springs, thus generating steam from interaction between hot ash and water. The expanding vapor blasts violently through the overlying deposits. The term "secondary hydroexplosion eruptions" was defined by Moyer and Swanson (1987) to describe eruptions driven by steam when surficial water vaporized during emplacement of a pyroclastic flow, as opposed to phreatic explosions that occur by the interaction of magma with groundwater. However, it is reasonable to assume that shallow pore water in the sediment, and water in fractures in the Devine Canyon Ash-flow Tuff also flashed to steam. This permitted the explosions to remove sedimentary materials and tuff from below the hot Rattlesnake deposit as these rootless eruptions continued over a period of days or weeks.

This interpretation for the origin of the pits is made by analogy to similarly shaped depressions in the pyroclastic-flow and debris-avalanche deposits of May 18, 1980, at Mount St. Helens (Rowley and others, 1981; Moyer and Swanson, 1987). The explosions took place within several days after hot pyroclastic flows covered streams and ponds in the Toutle River Valley and around Spirit Lake. Most of the depressions were 5 to $100 \mathrm{~m}$ in diameter and from 1 to $20 \mathrm{~m}$ deep. The largest explosion pit $(0.7 \mathrm{~km}$ long, $0.3 \mathrm{~km}$ wide, $38 \mathrm{~m}$ deep) was formed from migrating phreatic vents that coalesced to form a single elongate pit approximately in the former location of the North Fork of the Toutle River.

The geographic location of the pits is consistent with this interpretation. The depressions in the Rattlesnake Ashflow Tuff are exposed along a $25-\mathrm{km}$-long east-west arcuate zone concentric about, and $40 \mathrm{~km}$ south of Harney Lake, the possible source area for the Rattlesnake Ash-flow Tuff (Walker, 1979). At this distance from source, the tuff changes in map pattern from sheet-forming on the northwest to valley-filling on the southeast. It seems likely that this zone marks a change in paleotopography from flat ground with surface water on the northwest to gently sloping, better-drained ground south and southeastward toward Steens Mountain. Localization of explosion pits along this zone would have resulted where a sufficiently thin pyroclastic flow meets standing water; proximal parts of the flow may have been too thick to allow disruption or to preserve discrete craters.

\section{ACKNOWLEDGMENTS}

This report has benefitted from the reviews and constructive comments of Norm MacLeod, Scott Minor, and Ron LeCompte. Chemical analyses were kindly provided by Rick Conrey. I wish to acknowledge the hospitality shown by Mr. and Mrs. Dwight Hammond and ranchhands of the Hammond Ranch, major landholder in the quadrangle. 


\section{REFERENCES CITED}

Carlson, R.W., and Hart, W.K., 1983, Areal extent and isotope geochemistry of the Steens Mountain flood basalt, southeastern Oregon [abs.]: Eos (American Geophysical Union Transactions), v. 64 , no. 18, p. 338 .

Davenport, R.E., 1971, Geology of the Rattlesnake and older ignimbrites in the Paulina Basin and adjacent area, central Oregon: Corvallis, Oregon State University, Ph.D. dissertation, $132 \mathrm{p}$.

Draper, D.S., 1991, Late Cenozoic bimodal magmatism in the northern Basin and Range province of southeastern Oregon: Journal of Volcanology and Geothermal Research, v. 47 , no. $3 / 4$, p. 299-328.

Enlows, H.E., 1976, Petrography of the Rattlesnake Formation at the type area, central Oregon: Oregon Department of Geology and Mineral Industries Short Paper 25, $34 \mathrm{p}$.

Fiebelkorn, R.B., Walker, G.W., MacLeod, N.S., McKee, E.H., and Smith, J.G., 1983, Index to K-Ar age determinations for the state of Oregon: Isochron/West, no. 37, p. 3-60.

Fisher, R.V., and Schmincke, H-U., 1984, Pyroclastic rocks: New York, Springer-Verlag, 472 p.

Fuller, R.E., 1931, The geomorphology and volcanic sequence of Steens Mountain in southeastern Oregon: University of Washington Publications in Geology, v. 3, no. $1,130 \mathrm{p}$.

Greene, R.C., 1973, Petrology of the welded tuff of Devine Canyon, southeastern Oregon: U.S. Geological Survey Professional Paper 797, 26 p.

Greene, R.C., Walker, G.W., and Corcoran, R.E., 1972, Geologic map of the Burns quadrangle, Oregon: U.S. Geological Survey Miscellaneous Investigations Map I-680, scale $1: 250,000$.

Gunn, B.M., and Watkins, N.D., 1970, Geochemistry of the Steens Mountain Basalts, Oregon: Geological Society of America Bulletin, v. 81, no. 5, p. 1,497-1,516.

Hart, W.K., Aronson, J.L., and Mertzman, S.A., 1984, Areal distribution and age of low-K, high-alumina olivine tholeiite magmatism in the northwestern Great Basin, U.S.A.: Geological Society of America Bulletin, v. 95, no. 2 , p. 186-195.

Hart, W.K., and Carlson, R.W., 1985, Distribution and geochronology of Steens Mountain-type basalts from the northwestern Great Basin: Isochron/West, no. 43, p. 5-10.

-1987, Crustal genesis on the Oregon Plateau: Journal of Geophysical Research, v. 92, no. B7, p. 6,191$6,206$.

Hart, W.K., Carlson, R. W., and Mosher, S.A., 1989, Petrogenesis of the Pueblo Mountains basalt, southeastern Oregon and northern Nevada, in Reidel, S.R., and Hooper, P.R., eds., Volcanism and tectonism in the Columbia River flood-basalt province: Geological Society of America Special Paper 239, p. 367-378.

Johnson, J.A., and Sherrod, D.R., 1992, Phreatic pits in the southeast margin of the Rattlesnake Ash-flow Tuff, Harney Basin, southeastern Oregon [abs.]: Geologi- cal Society of America Abstracts with Programs, v. 24, no. 5 , p. 36 .

Lawrence, R.D., 1976, Strike-slip faulting terminates the Basin and Range province in Oregon: Geological Society of America Bulletin, v. 87, no. 6, p. 846-850.

Le Bas, M.J., Le Maitre, R.W., Streckeisen, A., and Zenettin, B., 1986, A chemical classification of volcanic rocks based on the total alkali-silica diagram: Journal of Petrology, v. 27, p. 745-750.

Macdonald, G.A., and Katsura, T., 1964, Chemical composition of Hawaiian lavas: Journal of Petrology, v. 5, p. 82133.

Mankinen, E.A., Prevot, Michel, Gromme, C.S., and Coe, R.S., 1987, The Steens Mountain (Oregon) geomagnetic polarity transition, 1. Directional history, duration of episodes, and rock magnetism: Journal of Geophysical Research, v. 90, no. B12, p. 10,393-10,416.

McKee, E.H., Duffield, W.A., and Stern, R.J., 1983, Late Miocene and early Pliocene basaltic rocks and their implications for crustal structure, northeastern California and south-central Oregon: Geological Society of America Bulletin, v. 94, p. 292-304.

Merriam, J.C., Stock, Chester, and Moody, C.L., 1925, The Pliocene Rattlesnake Formation and fauna of eastern Oregon, with notes on the geology of the Rattlesnake and Mascall deposits: Carnegie Institute of Washington Publication 347, p. 43-92.

Minor, S.A., 1986, Stratigraphy and structure of the western Trout Creek and northern Bilk Creek Mountains, Harney County, Oregon, and Humboldt County, Nevada; University of Colorado M.S. thesis, 177 p.

Minor, S.A., Plouff, D., Esparza, L.E., and Peters, T.J., 1987a, Geologic map of the High Steens and Little Blitzen Gorge wilderness study areas, Harney County, Oregon: U.S. Geological Survey Miscellaneous Field Studies Map MF1876 , scale $1: 24,000$.

Minor, S.A., Rytuba, J.J., Goeldner, C.A., and Tegtmeyer, K.J., 1987b, Geologic map of the Alvord Hot Springs quadrangle, Harney County, Oregon: U.S. Geological Survey Miscellaneous Field Studies Map MF-1916, scale $1: 24,000$.

Minor, S.A., Rytuba, J.J., Vander Meulen, D.B., Grubensky, M.J., and Tegtmeyer, K.J., 1987c, Geologic map of the Wildhorse Lake quadrangle, Harney County, Oregon: U.S. Geological Survey Miscellaneous Field Studies Map MF-1915, scale 1:24,000.

Moyer, T.C. and Swanson, D.A., 1987, Secondary hydroeruptions in pyroclastic-flow deposits: examples from Mount St. Helens: Journal of Volcanology and Geothermal Research, v. 32, p. 299-319.

Parker, D.J., 1974, Petrology of selected volcanic rocks of the Harney Basin, Oregon: Corvallis, Oregon State University, Ph.D. dissertation, 119 p.

Piper, A.M., Robinson, T.W., Jr., and Park, C.F., Jr., 1939. Geology and ground-water resources of the Harney Basin, Oregon: U.S. Geological Survey Water-Supply Paper 841,189 p.

Rowley, P.D., Kuntz, M.A., and MacLeod, N.S., 1981, Pyroclastic-flow deposits, in Lipman, P.W., and Mullineaux, D.R., eds., The 1980 eruptions of Mount 
St. Helens, Washington: U.S. Geological Survey Professional Paper 1250, p. 489-512.

Sherrod, D.R., and Johnson, J.A., 1994, Geologic map of the Irish Lake quadrangle, Harney County, south-central Oregon: U.S. Geological Survey Miscellaneous Field Studies Map MF-2256, scale 1:24,000.

Sherrod, D.R., Minor, S.A., and Vercoutere, T.L., 1989, Geologic map of the Sheepshead Mountains, Harney and Malheur Counties, Oregon: U.S. Geological Survey Miscellaneous Field Studies Map MF-2079, scale $1: 50,000$.

Stewart, J.H., 1978, Basin and range structure in western North America, in Smith, R.B., and Eaton, G.P., eds., Cenozoic tectonics and regional geophysics of the western Cordillera: Geological Society of America Memoir 152, p. 1-31.

Stimac, J.P., and Weldon, R.J., II, 1992, Paleomagnetism and tectonic rotations of the Rattlesnake and Devine Canyon Ash-flow Tuffs, northern Basin and Range, southern Oregon [abs.]: Geological Society of America Abstracts with Programs, v. 24, no. 5, p. 83.

Streck, M.J., 1991, Local and regional facies and facies variations within the Rattlesnake Ash-flow Tuff, a widespread ash flow sheet in eastern Oregon [abs.]: Eos (American Geophysical Union Transactions), v. 72, no. 44 , p. $568-569$.

Swisher, C.C., Ach, J.A., and Hart, W.K., 1990, Laser fusion ${ }^{40} \mathrm{Ar}-{ }^{39} \mathrm{Ar}$ dating of the type Steens Mountain Basalt, southeastern Oregon, and the age of the Steens geomagnetic polarity transition [abs.]: Eos (American Geophysical Union Transactions), v. 71, no. 43, p. 1,296.

Turrin, B.D., Griscom, Andrew, Turner, R.L., Lawson, W.A., Buehler, A.R., and Graham, D.E., 1989, Mineral resources of the Alvord Desert and East Alvord Wilderness Study Areas, Harney and Malheur Counties, Oregon: U.S. Geological Survey Bulletin 1739-B, 16 p.

Vander Meulen, D.B., Griscom, Andrew, King, H.D., and Moyle, P.R, 1988a, Mineral resources of the Blitzen River Wilderness Study Area, Harney County, Oregon: U.S. Geological Survey Bulletin 1740-D, 14 p.
Vander Meulen, D.B., Griscom, Andrew, King, H.D., and Vercoutere, T.L., 1988b, Mineral resources of the Home Creek Wilderness Study Area, Harney County, Oregon: U.S. Geological Survey Bulletin 1740-C, 12 p.

Walker, G.W., 1969a, Possible fissure vent for a Pliocene ash-flow tuff, Buzzard Creek area, Harney County, Oregon: U.S. Geological Survey Professional Paper 650C, p. C8-C17.

$-1969 \mathrm{~b}$, Some comparisons of the basalts of southeast Oregon with those of the Columbia River Group, in Proceedings of the Second Columbia River Basalt Symposium, Cheney, Washington: Cheney, Eastern Washington State College Press, p. 223-237.

-1969 c, Geology of the High Lava Plains Province, in Weissenborn, A.W., ed., Mineral and water resources of Oregon: Oregon Department of Geology and Mineral Industries Bulletin 64, p. 77-79.

-1977 , Geologic map of Oregon east of the $121 \mathrm{st}$ meridian: U.S. Geological Survey, scale 1:500,000.

-1979 , Revisions to the Cenozoic stratigraphy of Harney Basin, southeastern Oregon: U.S. Geological Survey Bulletin 1475, 35 p.

Walker, G.W., and Repenning, C.A., 1965, Reconnaissance geologic map of the Adel quadrangle, Lake, Harney, and Malheur Counties, Oregon: U.S. Geological Survey Miscellaneous Investigations Map I-446, scale $1: 250,000$.

Walker, G.W., and Swanson, D.A., 1968, Summary report on the geology and mineral resources of the Harney Lake and Malheur Lake areas of the Malheur National Wildlife Refuge, north-central Harney County, Oregon: U.S. Geological Survey Bulletin 1260-L, p. L1-L17.

Watkins, N.D., and Baksi, A.K., 1974, Magnetostratigraphy and oroclinal folding of the Columbia River, Steens, and Owyhee basalts in Oregon, Washington, and Idaho: American Journal of Science, v. 274, no. 2, p. 148-189. 